\title{
Spiked pepper: selection of clones toward cropping on the edaphoclimatic conditions from Belém, Brazil
}

\author{
José Maria D Gaia ${ }^{1}$; Milton Guilherme da C Mota ${ }^{1}$; Carmen Célia C da Conceição; ; José Guilherme S \\ Maia $^{2}$ \\ 'UFRA-ICA, C. Postal 917, 66077-530 Belém-PA; 2UFPA, C. Postal 479, 66075-110 Belem-PA; josegaia@globo.com
}

\begin{abstract}
Spiked pepper presents a high yield of essential oil with useful biological properties for human health and agriculture. In order to evaluate the morphoagronomic variability and, afterwards, to select genotypes for plant breeding and cultivation, thirteen clones were propagated. Thus, spiked pepper cuttings were rooted under greenhouse, transferred to a nursery and, afterwards, planted at the experimental area. The evaluations were carried out in two harvest seasons. The evaluated morphoagronomic traits were number of leaves per branch, leaf length, leaf width, diameter of the oldest branch, plant height, number of orthotropic branches, number of plagiotropic branches, internode length, fresh and dry matter, yield of essential oil and dillapiole content. The analysis of variance and the Scott-Knott test were utilized for data analysis and comparisons among clones and parentals were carried out through genetic and experimental variation coefficients. Fresh matter (first season), number of orthotropic branches and diameter of the the oldest branch (second season) presented variability. The Scott-Knott test detected variability for fresh matter, dillapiole content (first season), diameter of the oldest branch and number of orthotropic branches (second season). The yield of essential oil and the dillapiole content were higher for the clones than for the parentals. In conclusion, the clones showed adaptability to the soil and climate conditions of Belém, Pará State, Brazil; the harvest time influenced the oil yield and the dillapiole content; the variance analysis evidenced uniformity and productivity for the evaluated clones, suggesting they can be recommended for cultivation on small-scale production systems in this location.
\end{abstract}

Keywords: Piper aduncum L., genetic resources, conservation of germplasm, morphoagronomic traits, genetic breeding.

\section{RESUMO}

Pimenta-de-macaco: seleção de clones para plantio nas condições edafoclimáticas de Belém

Pimenta-de-macaco é uma espécie com elevado teor de óleo essencial em que se constatam propriedades biológicas utilizáveis na agricultura e saúde humana. Com o objetivo de avaliar a variabilidade morfoagronômica e selecionar genótipos, visando ao melhoramento genético e cultivo em sistemas de produção, foram propagados treze clones de pimenta-de-macaco. As estacas foram enraizadas em casa de vegetação, transferidas para viveiro e local definitivo. A tomada de dados realizou-se em duas épocas de colheita. Os caracteres morfoagronômicos avaliados foram número de folhas por ramo, comprimento da folha, largura da folha, diâmetro do ramo mais velho, altura da planta, número de ramos ortotrópicos, número de ramos plagiotrópicos, comprimento do entrenó, massa da matéria fresca, massa da matéria seca, rendimento de óleo essencial e teor de dilapiol. Utilizou-se de análise de variância e teste de Scott-Knott, além de comparações entre matrizes e clones por meio dos coeficientes genético e experimental de variação. Os caracteres massa da matéria fresca (primeira época), número de ramos ortotrópicos e diâmetro do ramo mais velho (segunda época) foram os que mostraram variabilidade. O teste de Scott-Knott detectou diferença na massa da matéria fresca, teor de dilapiol (primeira época), diâmetro do ramo mais velho e número de ramos ortotrópicos (segunda época). O rendimento de óleo e o teor de dilapiol apresentaram, nos clones, médias superiores às médias das matrizes. Concluiu-se que os clones mostraram adaptabilidade às condições edafoclimáticas de Belém; a época de colheita influiu sobre a produção de óleo e teor de dilapiol; a análise de variância e agrupamentos de médias evidenciaram uniformidade e produtividade nos clones examinados, podendo ser recomendados, nas condições edafoclimáticas de Belém, para cultivo em sistemas de produção, em pequena escala.

Palavras-chave: Piper aduncum L., recursos genéticos, conservação de germoplasma, caracteres morfoagronômicos, melhoramento genético.

(Recebido para publicação em 4 de maio de 2009; aceito em 19 de agosto de 2010)

(Received on May 4, 2009; accepted on August 19, 2010)

$\mathrm{S}_{\mathrm{p}}^{\mathrm{p}}$ piked pepper is an aromatic species found in the Brazilian Amazon. It presents a great potential for economic exploitation based on the confirmed possibility of utilization of the spiked pepper essential oil, which presents useful biological properties for industries and mainly for the natural agrochemical industry. The spiked pepper oil has been reported as fungicide, bactericide, molluscicide, acaricide, larvicide, insecticide and nematicide (Lobato et al., 2007; Silva et al., 2007). Such properties are attributed to the dillapiol, the major component of the spiked pepper essential oil, whose yield in the laboratory extraction process can range from $1.2 \%$ to $3.4 \%$ (Maia et al., 2000).

The spiked pepper presents a relatively short vegetative cycle, high tolerance to low-fertility acid soils, facility of vegetative propagation and a wide adaptation capacity to different environments (Albuquerque, 1980; Silva, 1993; Leme et. al., 1998; Francis, 2003). These characteristics can favor the plant domestication and cultivation, which can be an alternative to income generation for farmers, since the spiked pepper crop presents a high oil yield in 
comparison to other aromatic species.

Since spiked pepper can be domesticated, studies are developed to promote its feasible cultivation, such as the ones towards propagation, in which $90 \%$ of survival was observed in washed sand (Leme et al., 1998) and micropropagation of nodal fragments through the utilization of growth regulators (ANA and BAP), producing callus, which are important structures for the generation of chromossomic variation (Mantell et al., 1994; Ferreira et al., 2006).

For Piper hispidinervium, researches reported positive correlation between the safrole content and the essential oil yield (Pimentel et al., 1998), moment and frequency of harvesting and its effects on the oil yield (Bergo et al., 2005), which provided important information for the cultivation of this plant.

The present research aimed at evaluating and selecting spiked pepper clones towards the essential oil production, major constituent of the oil and morphologic variability for the genetic improvement and cultivation in amazonic production systems.

\section{MATERIAL AND METHODS}

Propagative materials of spiked pepper were identified and sent to the Universidade Federal Rural da Amazônia in Belém, Pará State, Brazil, where Afi (Köppen classification) is the climate type, with an average temperature of $32^{\circ} \mathrm{C}$, annual rainfall of $2.800 \mathrm{~mm}$, air moisture of $85 \%$, in a sand-silt soil.

In a greenhouse, thirteen primary clones were obtained, by preparing plantlets of $15 \mathrm{~cm}$ with two or three meristems per cutting, with one leaf, treated with a $1 \%(\mathrm{w} / \mathrm{v})$ fungicide (benomil) solution for ten minutes. After, the cutting was placed in a carbonized rice husk to promote the root growth, which was based in recommendations of Silva (1993). The plantlets were transferred to a nursery with $50 \%$ of shadow and, after, they were transferred to the final location.

The thirteen clones were planted following a randomized complete blocks design with three replications and plots of five plants in simple rows, spaced $0.6 \times 0.6 \mathrm{~m}$. There were, also, lateral borders in the experiment. The pits measured $20 \times 20 \times 20 \mathrm{~cm}$, with organic fertilization of about $5 \mathrm{~L}$ of duck manure/pit and NPK fertilization with a single application of $8 \mathrm{~g}$ of triple superphosphate, $5 \mathrm{~g}$ of urea and $6 \mathrm{~g}$ of potassium chloride, applied in three moments each 30 days as follows: urea in dosis of 3, 3 and $2 \mathrm{~g} / \mathrm{pit}$ and potassium chloride in dosis of 3,1 and $2 \mathrm{~g} / \mathrm{pit}$, based on recommendations of Silva (1993), Brasil et al. (1998) and Brasil \& Viégas (1998).

The first data collecting season was 11, 12 and 13 months after planting (February to April, 2002) and, the second, 17, 18 and 19 months after planting (August to October, 2002). One block was harvested per month, when the clones were cut $50 \mathrm{~cm}$ above the soil surface. During the harvest, the following characteristics were evaluated: 1) number of leaves per branch (NLS) from five branches of the plant central part; 2) leaf length (LL), measured in the fifth leaf of the fifth branch in the plant central part; 3) leaf width (LW), evaluated from the fifth leaf of the fifth branch of the plant central part; 4) diameter of the oldest branch (DOS), taken $20 \mathrm{~cm}$ above the soil surface; 5) plant height (PH), measured from the soil surface to the highest point in the plant; 6) total number of orthotropic branches (TNOS); 7) total number of plagiotropic branches (TNPS); 8) internode length (IL), measured $50 \mathrm{~cm}$ from the soil surface; 9) yield of essential oil (YEO), extracted from $100 \mathrm{~g}$ of leaves, which were dried under shadow; 10) dillapiole yield (DY), obtained from $100 \mathrm{~g}$ of leaves, which were dried under shadow; 11) fresh mass of leaves and thin branches(FMLTS) and 12) total dry matter of leaves and thin branches (TDMLTS).

The cut material was sent to the Phytochemistry Lab. of the Museu Paraense Emilio Goeldi, for the yield determination of oil and of the major component. The essential oil extraction was carried out through hydrodistillation, with Clevenger extractors, for three hours. The analysis of the essential oil chemical composition was carried out through a Hewlett Packard model 5890 gas chromatograph, utilizing a WCOT fused silica capillary column of $25 \mathrm{~cm}$ length, internal diameter of $0,25 \mathrm{~mm}$ and film width of $0,25 \mu \mathrm{m}$ and temperature program $60^{\circ} \mathrm{C} / 240^{\circ} \mathrm{C}\left(3^{\circ} \mathrm{C}\right.$ for minutes).

The data of the matrices, clones (first season) and clones (second season) were compared through means, experimental coefficients of variation and genetic variation coefficients, as well as through the ratio between these coefficients (CVg/CVe).

The data of clones (first and second seasons) were submitted to variance analysis and average grouping through the Scott-Knott test after the normality test (of Lilliefors), following the recommendations of Ramalho et al. (2000), for two harvest seasons.

The variables with non-normality were transformed according to their properties (if positive, integer from counting or percentage). Thus, the dry mass characters and the dillapiole content were transformed respectively through natural logarithm and arcsen $(\mathrm{x} / 100)^{1 / 2}$ in the first season and, in the second season, the diameter of the oldest branch, the fresh matter, the number of orthotropic branches, the number of plagiotropic branches and the essential oil yield were also transformed through natural logarithm, multiplication by itself (square), root of index 8, square root and $\left.\operatorname{arcsen}(\mathrm{x} / 100)^{1 / 2}\right)$. The calculations were carried out through the GENES software (Cruz, 2006).

\section{RESULTS AND DISCUSSION}

There was found a variation among clones, in the fresh matter (FMLTS) (first season), in the total number of orthotropic branches (TNOS) and in the diameter of the oldest branch (DOS) (second season).

In the first season, the effects over the fresh matter (FMLTS) can be attributed to the rainy season and, in the second season, the effects over the number of orthotropic branches and the diameter of the oldest branch can be related to the stimulation of the shoot production due to cutting and to the rapid growth, 
Table 1. Comparison of means from morphoagronomic traits evaluated on two harvest times. in primary spiked pepper's clones (comparação de médias de caracteres morfoagronômicos avaliados em duas épocas de colheita. em treze clones primários de pimenta-de-macaco). Belém, ICA-UFRA, 2008.

\begin{tabular}{lccccc}
\hline \multirow{2}{*}{$\begin{array}{l}\text { Scott-Knott test } \\
\text { Matrices }\end{array}$} & \multicolumn{2}{c}{$\mathbf{1}^{\text {st }}$ Season } & & \multicolumn{2}{c}{$2^{\text {nd }}$ Season } \\
\cline { 2 - 3 } \cline { 5 - 6 } \cline { 5 - 6 } PA-001 & FMLTS & DY & & DOS & TNOS \\
PA-002 & $3.8 \mathrm{f}$ & $86.3 \mathrm{a}$ & & $87.2 \mathrm{a}$ & $14.7 \mathrm{~b}$ \\
PA-003/01 & $4.8 \mathrm{~b}$ & $82.7 \mathrm{~d}$ & & $93.6 \mathrm{a}$ & $18.0 \mathrm{a}$ \\
PA-003/02 & $3.5 \mathrm{~h}$ & $75.6 \mathrm{e}$ & & $87.0 \mathrm{a}$ & $17.3 \mathrm{a}$ \\
PA-004 & $3.8 \mathrm{e}$ & $84.6 \mathrm{c}$ & & $81.4 \mathrm{~b}$ & $19.0 \mathrm{a}$ \\
PA-005 & $5.0 \mathrm{a}$ & $82.1 \mathrm{~d}$ & & $95.7 \mathrm{a}$ & $17.0 \mathrm{a}$ \\
PA-006 & $3.8 \mathrm{e}$ & $84.7 \mathrm{c}$ & & $91.4 \mathrm{a}$ & $14.7 \mathrm{~b}$ \\
PA-007 & $3.5 \mathrm{i}$ & $85.3 \mathrm{~b}$ & & $99.4 \mathrm{a}$ & $15.3 \mathrm{~b}$ \\
PA-008 & $3.9 \mathrm{~d}$ & $84.2 \mathrm{c}$ & & $98.4 \mathrm{a}$ & $13.0 \mathrm{~b}$ \\
PA-009/01 & $3.1 \mathrm{j}$ & $83.0 \mathrm{~d}$ & & $79.9 \mathrm{~b}$ & $14.7 \mathrm{~b}$ \\
PA-009/02 & $3.6 \mathrm{~g}$ & $85.0 \mathrm{c}$ & & $91.4 \mathrm{a}$ & $18.3 \mathrm{a}$ \\
PA-010 & 1.91 & $82.5 \mathrm{~d}$ & & $89.3 \mathrm{a}$ & $13.3 \mathrm{~b}$ \\
PA-011 & $4.5 \mathrm{c}$ & $85.7 \mathrm{~b}$ & & $93.4 \mathrm{a}$ & $14.3 \mathrm{~b}$ \\
\hline
\end{tabular}

FMLTS: mass of the fresh matter (massa da matéria fresca $(\mathrm{kg})$; DY: content of dillapiole (teor de dilapiol (\%); DOS: diameter of the older branch (diâmetro do ramo mais velho $(\mathrm{cm})$; TNOS: number of orthotropic branches (número de ramos ortotrópicos); Values followed by the same letters belong to the same mean cluster (números seguidos de letras iguais pertencem ao mesmo grupo de médias).

which is characteristic of the species (Leme et al., 1998).

In the first season, only two variables formed groups of means through the Scott-Knott test: the fresh mass (FMLTS) and the dillapiole yield (DY) (Table 1). In the fresh matter, each clone formed one group, except for the clones PA003-02 and PA-005, which presented the same average value (3.8); the highest value was presented by the clone PA005 (5.0) and the lowest by the clone PA-009/02 (1.9).

In the dillapiole yield, five groups of means were formed. The first and the latest groups were formed by a single clone: PA-001 (86.3a) and PA-003/01 (75.6e), respectively. The second group comprised two clones: PA-010 (85.7b) and PA-006 (85.3b). The intermediate group comprised five clones, in which the highest average value was presented by the clone PA-009/01 (85.0c) and the lowest value was presented by the clone PA-007 (84.2c). The fourth group comprised four clones, in which the highest mean was observed in the clone PA-008 (83.0d) and the lowest was observed in the clone PA-004 (82.1d).

The formation of groups of means in the variable dillapiole yield can be a clue that there is variability for this trait and also for oil yield, if the two traits were positively correlated. In long pepper, the safrole yield was positively correlated to the yield of essential oil (Pimentel et al., 1998), which is a clue that this correlation can also exist in spiked pepper.

The other variables presented average values, whose contrasts were not significant. Thus, they formed a single group of means, which ranged from 6.7 to 8.5 (plant height, $\mathrm{PH}$ ), 12.7 to 17.0 (total number of orthotropic branches, TNOS), 68.3 to 83.3 (total number of plagiotropic branches, TNPS), 51.3 to 76.7 (number of leaves per branch, NLS), 79.9 to 88.3 (leaf length, LL), 26.3 to 30.3 (leaf width, LW), 23.0 to 40.6 (internode length, IL), 59.7 to 94.7 (diameter of the oldest branch, DOS) and 3.1 to 3.9 (yield of essential oil, YEO).

In the second season, the diameter of the oldest branch and the total number of orthotropic branches were the only variables which formed groups of means (Table 1). Towards the DOS, two groups of means were formed. The first, with the highest values, was formed by ten clones, with the highest value of 99.4 (PA-006) and the lowest value of 87.0 (PA-003/01). The second group assumed the lowest values and was formed by the clones PA-003/02 (81.4), PA-008 (79.9) and PA-011 (77.1).

Towards the TNOS, two groups were established. The first, with the highest means, was formed by five clones, with the highest average value of the clone PA-003/02 (19.0) and the lowest of the clone PA-004 (17.0). The second group was formed by eight clones, with the highest value of the clone PA-006 (15.3) and the lowest value of the clone PA-007 (13.0).

The production in the second season was possibly higher than in the first one, due to an addition of $57.6 \%$ per ha $(4.6 \%$ per plot) in the production of essential oil, and $46.5 \%$ per ha $(58.3 \%$ per plot $)$ in the dry matter production, in relation to the first harvest season (Table 2).

The production in the first season was estimated in $6.7 \mathrm{t} \mathrm{ha}^{-1}$ of dry matter and $0.39 \mathrm{t} \mathrm{ha}^{-1}$ of essential oil and, in the second one, the production was estimated in $10.5 \mathrm{t} \mathrm{ha}^{-1}$ of dry matter and $0.39 \mathrm{t} \mathrm{ha}^{-1}$ of essential oil, which totalized, after 18 months, 17.2 $\mathrm{t} \mathrm{ha}^{-1}$ of dry matter and $0.621 \mathrm{t} \mathrm{ha}^{-1}$ of essential oil. With a higher number of harvests, more expressive results should be obtained. Nevertheless, although the calculations were performed to one hectare, the agricultural growing conditions are different from the experimental ones, which occupy a small area and, consequently, the experimental conditions suffer lower environmental influence, which produces a significant experimental error.

By comparing the average values and the coefficient of variation of the oil yield and the dillapiole content of the matrices to the values of the primary clones (Table 3 ), the average value of the matrices $(2.7 \%)$ was inferior to the oil yield of the first season (3.5\%), which was more humid and, this was inferior to the oil yield observed in the second season (3.6\%), wich was drier.

The same behavior was not observed in the dillapiole content in relation to the means, which increased from the matrices $(79.8 \%)$ in the first season - 
Table 2. Average values of the mass of the dry matter and yield of essential oil of spiked pepper in two harvest times. presented per plot and per hectare (valores médios da massa da matéria seca e rendimento de óleo essencial de pimenta-de-macaco. tomados por parcela e por hectare, na primeira e na segunda colheita). Belém, ICA-UFRA, 2008.

\begin{tabular}{|c|c|c|c|c|c|c|c|c|}
\hline \multirow{3}{*}{ Clone } & \multicolumn{4}{|c|}{$1^{\text {st }}$ harvest } & \multicolumn{4}{|c|}{${ }^{2 n d}$ harvest } \\
\hline & \multicolumn{2}{|c|}{ TDMLTS (kg) } & \multicolumn{2}{|c|}{ YEO (\%) } & \multicolumn{2}{|c|}{ TDMLTS (kg) } & \multicolumn{2}{|c|}{ YEO (\%) } \\
\hline & Plot & ha & Plot & ha & Plot & ha & Plot & ha \\
\hline PA-001 & 1.3 & $7,222.2$ & 3.5 & 252.8 & 1.8 & $10,166.7$ & 3.8 & 390.4 \\
\hline PA-002 & 1.4 & $7,888.9$ & 3.9 & 306.8 & 2.2 & $12,000.0$ & 3.8 & 456.0 \\
\hline PA-003/01 & 1.2 & $6,500.0$ & 3.6 & 231.4 & 2.0 & $10,944.5$ & 3.5 & 387.4 \\
\hline PA-003/02 & 1.4 & $7,611.1$ & 3.6 & 271.0 & 1.8 & $10,000.0$ & 3.7 & 374.0 \\
\hline PA-004 & 1.8 & $9,777.8$ & 3.3 & 319.7 & 1.9 & $10,722.2$ & 3.5 & 377.4 \\
\hline PA-005 & 1.4 & $7,722.2$ & 3.3 & 251.7 & 1.8 & $9,944.5$ & 3.4 & 342.1 \\
\hline PA-006 & 0.9 & $5,222.2$ & 3.5 & 184.3 & 1.8 & $9,777.8$ & 3.4 & 334.4 \\
\hline PA-007 & 1.4 & $7,666.7$ & 3.1 & 236.9 & 1.6 & $9,111.1$ & 3.5 & 318.9 \\
\hline PA-008 & 0.9 & $5,111.1$ & 3.4 & 172.8 & 1.6 & $8,888.9$ & 3.7 & 328.9 \\
\hline PA-009/01 & 1.3 & $7,111.1$ & 3.5 & 249.6 & 1.6 & $9,111.1$ & 3.7 & 334.4 \\
\hline PA-009/02 & 0.5 & $2,722.2$ & 3.7 & 101.3 & 3.3 & $18,333.3$ & 3.6 & 667.3 \\
\hline PA-010 & 1.4 & $7,555.6$ & 3.6 & 272.0 & 1.9 & $10,555.6$ & 3.6 & 376.8 \\
\hline PA-011 & 0.9 & $4,833.3$ & 3.2 & 155.2 & 1.4 & $7,500.0$ & 3.8 & 376.8 \\
\hline Means & 1.2 & $6,688.0$ & 3.5 & 231.2 & 1.9 & $10,542.7$ & 3.6 & 389.6 \\
\hline
\end{tabular}

TDMLTS, mass of the dry matter (massa da matéria seca); YEO, yield of essential oil (rendimento de óleo essencial); ha: hectare (hectare).

more humid $(83.5 \%)$, but decreased in the second season - drier $(80.7 \%)$.

The experimental coefficients of variation of the oil yield and the dillapiole content were lower than the coefficients of variation in natural conditions and they were higher, towards the essential oil yield, in the drier season. In this season, the production was higher whereas, in the dillapiole content, the production was higher in the humid season. This can be explained by assuming that the plant concentrates more efforts in the oil production in the drier season in order to preserve and/or to avoid the loss of water of its vegetative parts (thin branches and leaves) to the environment. It can be corroborated with information from Conceição (2000), which, in a review about plants which are producers of secondary metabolites, such as the volatile oils, reports that when those plants are moved from their habitats, they reduce their production of active substances and that the formation and accumulation of essential oils are likely to increase in drought conditions. Correlation between the essential oil yield and its major constituent (safrole) was also reported by Pimentel et al. (1998) in long pepper.
The genetic variation index, given by the ratio between the $\mathrm{CVg}$ and the $\mathrm{CVe}$ decreased from the first to the second season in the oil yield and in the dillapiole yield. In the case of oil yield, the reduction was due to the $\mathrm{CVe}$, since the $\mathrm{CVg}$ remained the same. In the case of the dillapiole, both coefficients were reduced. The attainment of a negative $\mathrm{CVg}$ in the oil yield can be a clue that the plant requires a more robust experimental design in order to provide a reduction in the experimental error. Nevertheless, it depends on the development of statistic studies for the optimization of the plot size in order to make the estimate of such parameters present the desired accuracy and also to consider the whole productive plant cycle, providing the plant the expression of its total genetic potential.

Considering the generality of the variables, the results show that the evaluated clones present a high phenotypic similarity, which increase the uniformity of the material, which, in addition to productivity, is a desirable trait for the cultivation and commercial production.

Two other traits, which qualify the thirteen evaluated clones for the commercial cultivation, are the facility towards the vegetative propagation (Leme et al., 1998) and the high essential oil yield, when compared to other aromatic species (Maia et al., 2000), besides its remarkable rusticity and adaptability (Gaia, 1998). Thus, the evaluated clones are promising due to their good traits, which favor the cultivation and the commercial production. It makes them likely to be recommended to cultivation in small scale production systems. Nevertheless, other aspects are necessary to be considered in the evaluation process, such as tolerance to plagues and diseases, adaptation to diverse soil and environmental conditions to make them certainly recommended for commercial scale production.

The clones presented good adaptation to the soil and environmental conditions of Belém, with a superior productive perform when compared to the natural conditions of Manaus, towards the variables essential oil yield and dillapiole content. The harvesting moment influenced the essential oil production and the dillapiole content suggesting the drier season is more appropriate to the production of essential 
Table 3. Means of spiked pepper's primary clones and parentals collected on the Brazilian Amazon for evaluation of the yield of essential oil in two harvest times (médias de matrizes e clones primários de pimenta-de-macaco coletados na Amazônia brasileira para avaliação do rendimento de óleo essencial em duas épocas de colheita). Belém, ICA-UFRA, 2008.

\begin{tabular}{|c|c|c|c|c|c|c|}
\hline \multirow{2}{*}{ Genotypes } & \multicolumn{2}{|c|}{ Matrices } & \multicolumn{2}{|c|}{ Clones ( $1^{\text {st }}$ season $)$} & \multicolumn{2}{|c|}{ Clones ( $2^{\text {nd }}$ season) } \\
\hline & YEO (\%) & DY (\%) & YEO (\%) & DY (\%) & YEO (\%) & DY (\%) \\
\hline PA-001 & 2.6 & 76.9 & 3.5 & 86.3 & 3.8 & 81.1 \\
\hline PA-002 & 2.8 & 85.3 & 3.9 & 82.7 & 3.8 & 80.5 \\
\hline PA-003/01 & 2.2 & 79.2 & 3.6 & 75.6 & 3.5 & 81.5 \\
\hline PA-003/02 & 2.4 & 78.7 & 3.6 & 84.6 & 3.7 & 82.0 \\
\hline PA-004 & 2.8 & 75.4 & 3.4 & 82.1 & 3.5 & 81.0 \\
\hline PA-005 & 2.4 & 76.3 & 3.4 & 84.7 & 3.4 & 78.7 \\
\hline PA-006 & 2.6 & 76.1 & 3.5 & 85.3 & 3.4 & 80.6 \\
\hline PA-007 & 3.3 & 83.1 & 3.1 & 84.2 & 3.0 & 80.4 \\
\hline PA-008 & 2.8 & 82.1 & 3.4 & 83.0 & 3.7 & 80.5 \\
\hline PA-009/01 & 3.4 & 82.9 & 3.5 & 85.0 & 3.7 & 80.1 \\
\hline PA-009/02 & 2.0 & 75.5 & 3.7 & 82.5 & 3.6 & 80.3 \\
\hline PA-010 & 3.6 & 81.5 & 3.6 & 85.7 & 3.6 & 80.9 \\
\hline PA-011 & 2.3 & 84.7 & 3.2 & 84.3 & 3.8 & 81.7 \\
\hline Means & 2.7 & 79.8 & 3.5 & 83.5 & 3.6 & 80.7 \\
\hline CVe (\%) & 18.5 & 4.5 & 14.1 & 3.9 & 7.6 & 1.8 \\
\hline CVg (\%) & --- & --- & -99.0 & 16.9 & -99.0 & 0.5 \\
\hline $\mathrm{CVg} / \mathrm{CVe}$ & --- & --- & -7.0 & 4.3 & -13.0 & 0.3 \\
\hline
\end{tabular}

YEO: yield of essential oil (rendimento de óleo essencial); DY: content of dillapiole (teor de dilapiol); CVe: coefficient of experimental variation (coeficiente de variação experimental); CVg: coefficient of genetic variation (coeficiente genético de variação).

oil with lower dillapiole content and the more humid season is more appropriate to the production of oil with higher dillapiole content. The oil production, in general, was likely superior in the second season. The variance analysis and the test of means, in general, evidenced the uniformity of the clones, but few variables showed variability with the plant growth. The productivity and the uniformity presented by the clones make them recommendable for cultivation in small-scale production systems in the soil and environmental conditions of Belém.

\section{AKNOWLEDGEMENTS}

The author thanks PROBEM and $\mathrm{CNPq}$ for the resources which comprised the collecting works and the installation of the germplasm collection. The author also thanks the team of researchers and trainers of the Museu Paraense Emílio Goeldi, for the contribution in the essential oil analysis and the botanical identification of the collected material.
Particularly, the author thanks CAPES, by the scholarship awarded to the first author.

\section{REFERENCES}

ALBUQUERQUE JM. 1980. Identificação de plantas invasoras de culturas da região de Manaus. Acta Amazônica 10: 47-95.

BERGO CL; MENDONÇA HA; SILVA MR. 2005. Efeito da época e freqüência de corte de pimenta-longa (Piper hispidinervium $\mathrm{C}$. DC.) no rendimento de óleo essencial. Acta Amazônica 35: 111-117.

BRASIL EC; POLTRONIERI L; VIÉGAS IJM. 1998. Influência da adubação potássica na incidência de Corynespora cassiicola em plantas de pimenta-longa (Piper hispidinervium). In: REUNIÃO BRASILEIRA DE FERTILIDADE DO SOLO E NUTRIÇÃO DE PLANTAS, 23. REUNIÃO BRASILEIRA DE MICORRIZAS， 7; SIMPÓSIO BRASILEIRO DE MICROBIOLOGIA DO SOLO, 5. Anais... Caxambu: SBCS/SBM/ DCS-UFLA.

BRASIL EC; VIÉGAS IJM. 1998. Efeito da adubação mineral na produção de matéria seca de pimenta-longa (Piper hispidinervium). Belém: Embrapa Amazônia Oriental. 4p. (Pesquisa em Andamento, 180).

CONCEIÇÃO CCC. 2000. Ocorrência e caracterização botânica e fitoquímica de sacaca (Croton cajucara Benth.) no nordeste paraense. Belém-PA: UFRA. 76p. (Tese mestrado).

CRUZ CD. 2006. Programa Genes: Análise multivariada e simulação. Viçosa-MG: Editora UFV. $175 p$.

FERREIRA GM; MOTA MGC; VIEIRA IMS; BATISTA MSF; SILVA SPG; CONCEIÇÃO CCC. 2006. Propagação in vitro de Piper aduncum L. Revista de Ciências Agrárias 45: 235-242.

FRANCIS JK. 2003. Piper aduncum L. San Juan: INTERNATIONAL INSTITUTE OF TROPICAL FORESTRY - UNIVERSITY OF PUERTO RICO. $3 \mathrm{p}$.

GAIA, JMD. 1998. Coleta, caracterização, avaliação e seleção em germoplasma de pimenta-de-macaco (Piper aduncum L.). Belém-PA: UFRA. 160p. (Tese doutorado).

LEME R; COUTO LB; LEAL FILHO N; GRIBEL R. 1998. Propagação por estaquia de duas espécies de piperáceas, Piper aduncum L. e Piper arboreum Aublet: estratégias para recuperação de áreas degradadas na Amazônia Central. Manaus: INPA. $4 \mathrm{p}$.

LOBATO AKS; SANTOS DGC; CASTRO DS; TORRES GIOPS; OLIVEIRA NETO CF; SILVA MHL. 2007. Avaliação dos efeitos da temperatura e da restrição hídrica sobre a germinação de sementes de Piper aduncum L. Revista Brasileira de Biociências 5: $297-$ 299, supl. 2.

MAIA JGS; ZOGHBI MGB; ANDRADE EHA. 2000. Plantas aromáticas na Amazônia e seus óleos essenciais. Belém: MPEG. 186p.

MANTELL SH; MATTHEWS JA; McKEE RA. 
1994. Princípios de biotecnologia em plantas uma introdução à engenharia genética em plantas. Ribeirão Preto: SBG. 344p.

PIMENTEL FA; PEREIRA JBM; OLIVEIRA MN. 1998. Zoneamento e caracterização de habitats naturais de pimenta-longa (Piper hispidinervium) no Acre. Rio Branco: Embrapa-
CPAF, 17p. (Boletim de pesquisa, 20).

RAMALHO MAP; FERREIRA DF; OLIVEIRA AC. 2000. Experimentação em genética e melhoramento de plantas. Lavras: UFLA. $326 \mathrm{p}$.

SILVA GS; PEREIRA AL; BASTOS CN; MENDONÇA VCM. 2007. Efeito da incorporação de resíduos foliares de Piper aduncum L. ao solo sobre o parasitismo de Meloidogyne incognita em tomateiro. Nematologia Brasileira 30: 219-222.

SILVA MHL. 1993. Tecnologia de cultivo e produção racional de pimenta-longa (Piper hispidinervium C. DC). Itaguaí-RJ: UFRRJ. 87p. (Tese mestrado). 